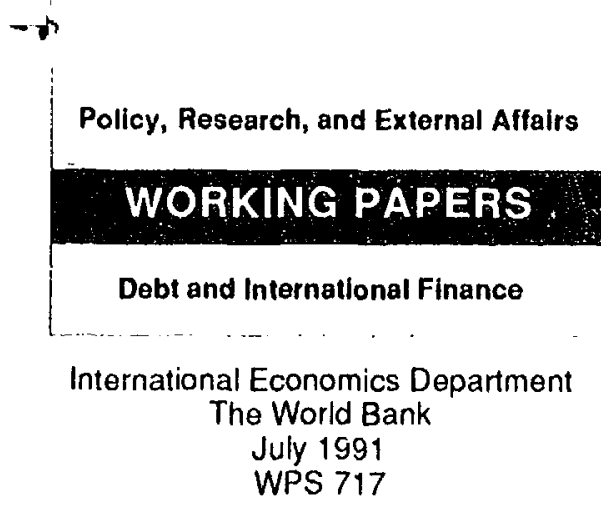

\title{
Does Financial Liberalization Really Improve Private Investment in Developing Countries?
}

Jacques Morisset

An increase in real interest rates, which is a typical element of financial reforms, does not necessarily involve a positive effect on private investment unless the authorities are careful to ensure that (1) bank deposits are closer substitutes to unproductive assets (cash, gold) and foreign assets than to capital goods, (2) the financial sector assures an efficient allocation of domestic credit, and (3) the flow of domestic credit to the private sector is not absorbed by the needs of the public sector. 


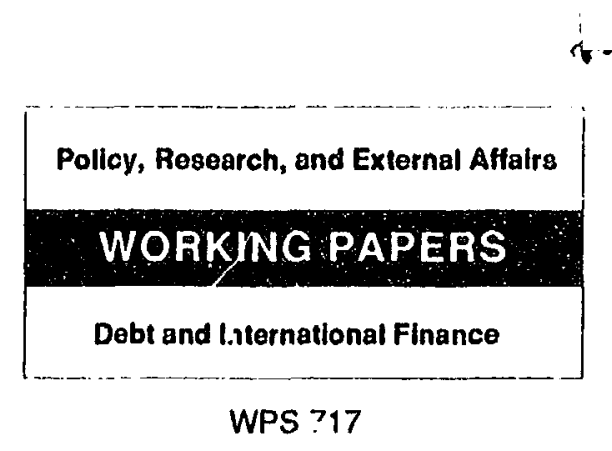

This paper - a product of the Debt and International Finance Division, International Economics Department - is part of a larger effort in PRE to determine the interaction between external and domestic finance in support of investment in devcloping countrics. Copies are available free from the World Bank, 1818 H Street NW, Washington DC 20433. Please contact Sheilah King-Watson, room S8-045, extension 31047 (22 pages).

Assuming that liquidity constraints exist in most developing countries, the majority of analysts believe that increasing real interest rates will raise the volume of lending and hence private investment.

Morisset, focusing on the demand for capital goods, argues that the positive cffect on the domestic credit market may be offset by the negative effect of a portfolio shift from capital goods and public bonds into monetary assets. He also demonstrates that a policy of financial liberalization could increase the public sector's demand for domestic credit, thus limiting the funds available to the private sector. This crowding out does not result from a change in the government's behavior but from a shift in the portfolio of private agents. Higher demand for bank deposits reduces the private sector's willingness to hold government bonds, so the public sector must finance a given budget deficit with more domestic credit.

His simulations for Argentina for 1961-82 suggest that the low response of private investors to changes in interest rate policy in those 20 ycars was attributable not to the low values of interest elasticities but to the interaction of the mechanisms allowed for in the model, which tends to neutralize the impact of such policies.

Morisset concludes that the effect of changes in interest rate policy on the demand for capital goods is weak in Argentina - and might affect the quality of private investment more than its quantity. 


\section{Table of Contente}

\section{Introduct Ion}

1. A stople Portfollo Model

2. The Flexible Accolergtor Model of Investment 8

3. The Introduction of the gublic sector 10

4. Ar mplricel Tere \& the Coee of Argenedoo (1961-82) 13

5. Concluding Remarks 16

$\begin{array}{ll}\text { BiblLography } & 17\end{array}$

$\begin{array}{lr}\text { Table8 } & 19\end{array}$

I em grereful to M. Blejer. A. Floblow, J. de Melo and rwo anonymous referee for helpful comments and suggestions. 


\section{Introduction}

In the economic literature. the relationship between real interest and privace inveotment in LDCs has recelved considerable actention. Unt I the early 1970s, the economists sssumed that low interest rates would promote investment spending and economic growth in accordance with Keynesisn and neoclassical theorles. Mckinnon (1973) and Shaw (1973) were the flrst to challenge seriously this conventional wisdom. These two authose auggested that higher real interest rates would ralse savings, incresee the volume of domestic credits extended by the SInenclel system and hence the equilibrium rato of Invertmene. In order to 88898 the McKinnon-Shaw hypothesis, an impressive number of empirical studies have been carried out during recent year2/. In the present state of research, the tendency is to admit the validity of this hypothes 18. As matter of fact. "establishing high real laterest gates hes become a standard part of the policy advice given to LDC'B by external experts, ranging from the visiting academic economist via the World Bank to emls8arles of the IMP" (8ee Van Wijnbergen (1983) or Polak (1989)).

The most favored justificstion for a high interest rates policy in LDCs 18 derived from the presence of Ilquidity constraints on private investment decisions. Pollcles the impose artificially low interest rate collings tend to constrain tho supply of capital and lead to an excess demand for capital relative to what would happen if the deposit Interar rate were allowed to find its marker-clearing level. Because the principal constraint on Investment is the quantity. rather than the cost, of financial resources, 8180 in incerese rates will increase the supply of credit to finance privare investment. "Any effect exerted by the rete of interest on private snvegtment 18 not direct within this rationing framework but, rather, occurs via the channel of financial 8avings" (Blejer an Than (1984), p.386). Even if a clear consensus bss emerged in recent years that a significant fraction of the population in developing countries 18 affected by liquidity constraints $3 /$. the problemetic issue is how far to go. We argue, by focusing on the demand for capits goods, that number of factors might Influence the relationship between real interest rates. the supply of domestic credits and privare Lnvostment.

The purpose of thds peper do to consront the Kckinnon-Shaw hypothesis with olmplo model of drvearment behevior. The resulting

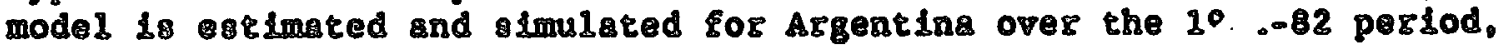
giver thet this country hos been affected by waglous drie. st retes

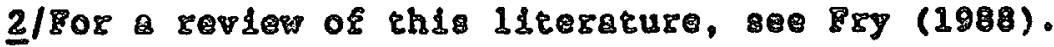

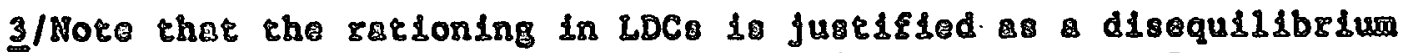
phenomenon caured by legal cellings on Interest retes. By conerset, for developed counterles, the argunent 18 based os moders theortes of Lopersect infonmerion. 
policles during the last twenty years4/. Simulation results indicare that. In the case of Argentins. the quantity of private investment is Iittle responodve to movements in incerest retes. While this finding moy not be entirely unexpected (e.g. Khatkhete (1988)). It appearo that th1s insensitfiley is not due to the low values of some important parameters. but rather to the incersctions of many opposing forces allowed by the model. In partcular. wild demonotrate that the positdve effect sugge日ted by McKinnon and Shaw may be offret slushtaneously by a crowding out effect and ontft that could occur in the portfollo of the grivgte sector.

The paper proceeds as follows. In section 1 we present a 8 implified portfollo model. Although this approsch 18 derived from a Tobir-Sidrauski framework, liquidity constraint is introduced into the model in accordance with the McRinnon-Shaw bypothes18. The demand for capital accumulation by the users of capital goods 18 specifled in section 2 using a modisied version of the flexible accelerator theory of investment. Section 918 devoted to the demonatration that the positive impact of a rise in interest rates on the oupply of domestic credits to finance private investment might be reduced or even reversed when the public aector 18 introduced into the analyols. The equations constituting the complete model are presented in table 2. The empirical results for Argentine are presented and discussed in section . Finsliy. sectlon 5 contalns our conclusion.

\section{Stmple Bortfolio Mode1}

An Lncrease in real incerort rates following a flnancial liberalization generates, in general, a portfollo ahift in favor of bank deposits. The authors in favor of the Mcrinnon-Shaw hypothes ds assume that this portfollo shift 18 coming out from unproductive eseets such as cash and gold. This seems, however, draste simplification of the reallty because it 18 not at all obvious that deposits are closer substitstes to these unproductive assets than to capital goods in LDCs. To illustrate this point. private davestment in LDGs 18 mosty the demand for capteal accumulation by the owner of capital (see thatkhate (1988, p.580)). This form of savings tends to decline when real incerest rates rise and correspondingly seving in flnancial assets goes up. Unles the latter effect dominates oignificantly the fosmer effect. privete resl lavestment may not regloter an upwards change with the rise In the real Interest rate. In this section, we address the critdcal 18sue of whether the positive effect suggested by McRlnnon and Shaw 18 strong onough to offset the shdfe from capital goods into monetary arsets that could occur la the portfolio of private agents.

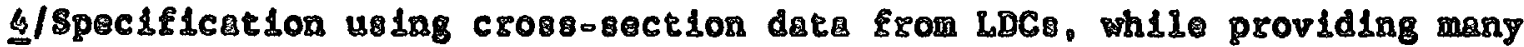

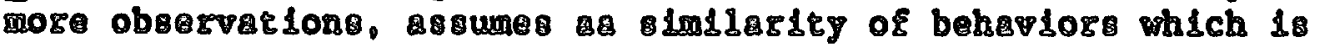
questorable.
} 
As arsting polnt, we consides the followling gesd budget congeralat for the prdvace sectorgl :

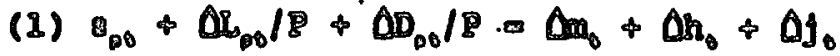

The privete sector can accumulate aseets into threo componests 8 real domertic money ( $\mathrm{m}$ ), real domertc aseets $(\mathrm{Ah})$ and real forelgr 8a8etr ( J). Equation (1) 8tates that prdvate expenditure for net accumbation of agsets 18 constrained by the amount of real private 8aving $\left(B_{0}\right)$. the changes in net real domeotlc credite to the private sector extended by the banking eystem $\left(L_{0} / P\right)$ and the changes in 8508 real private external debt $\left(D_{p} / P\right)$.

The demand for real monetary asete 18 defined as the changes in the stock of mones M3. Although foreign assets purchasing by residente are not recent, no such direct messures are avallable for developing countr1e8. Therefore capltal flight 18 used as representative of thlo form of sevings. The defindtion proposed by the World Bank (1985) appears to be the most appropriate to messure foreign assets holdings by the private sector since it does not distinguish between "normsl" capital flows and capital slights

(2) $0 f_{0}=\left(\Delta D_{0}+I B_{0}-\Delta R_{0}\right) / P=E_{0}$

Thls definition of cepltal filight takes Lnflow of capital in the form of increases in gross external debt $(D)$ and net forelgn direct investment (I*) and subtrects from these inflows the current account deficit (E) and the incresse in officiel reserves (R). The difference betreen these Inflows and the extent to which they are used to flnance the current account deficit and increase in reserves ls taken to reflect an increase in net foreign claims by the private sector ( $j)$.

Finsliy. real domestic assete $(\mathrm{Ah})$ are nothing but the difference between the financing available to the private sector and the two componenes defined above. Thus 8

(3) $\Delta h_{b}=a_{p t}+\Delta D_{p t} / P+\Delta b_{p \theta} / P-\Delta q_{p}-\Delta j_{\theta}=i_{p \theta}+\Delta b_{b}$

Real domestic assets include the amounts of physical capital ( $\left.1_{p}\right)$ and public bonds ( b) that the private sector can accumulate. Government bonds are assumed to be net wealth to the private sector because 1Lquiddty constralnts, by preventing the optimal consumption-savings decisions fron belng realized, can make present taxation less desirable to households than future tasation (e.g. Haque (1988)).

5/Since the model is designed explicitly for empirical testing, wo do not distinguish flrms and households in (1). Indeed, if wo assume thar all Elrms equitles are held by households, this asset can be elininated Erom (1). Burthermore. Tybout (1986) suggested that both behaviogs can be specifled by a portfolio model. 


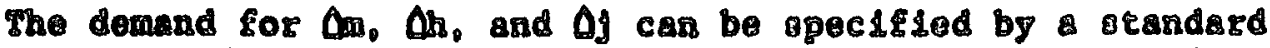
portfoldo mode16/. Por 8 lmpl1e1ty. we s88ume that the amoune of

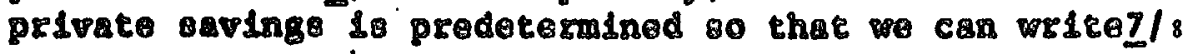

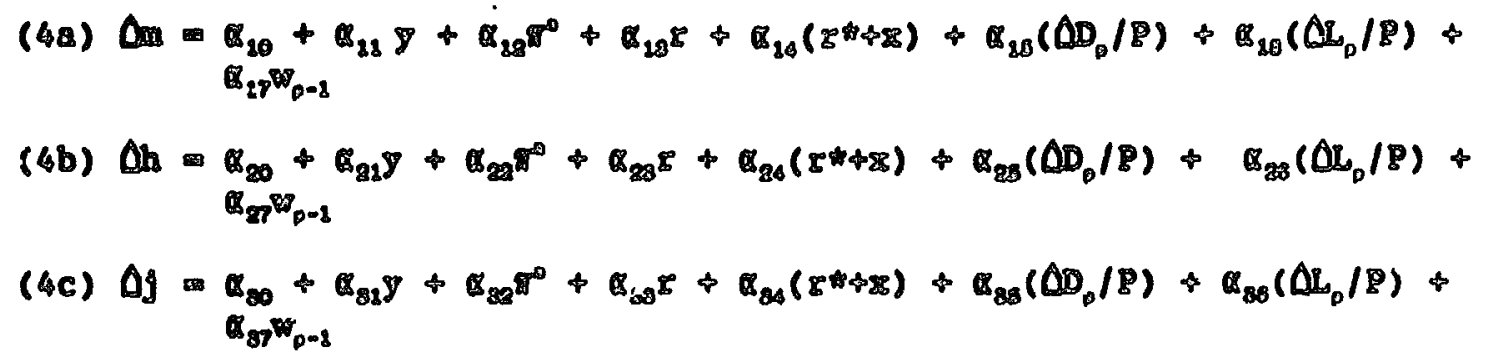

where $t$ is defined as the ex ante donestic real lnterest rate on deposits. the forelgn real interest rate, $x$ as the expected sate of depreciation of the local currency. 98 real income. ${ }^{\circ}$ as the expected rate of 1 fliation and $w_{p}$ as net real wealth sccumulated by the private sector.

The demand functions (4) are based on the theoretical arguments proposed by Brainard-Tobin (1968) and Purvis (1976). These suthors suggested that assets demands depend essentlally of the disposable income, the level of private wealth held in beglaning of perlod and the rates of returs on alternative $8880 t 8$. We defined the return on money as the ex ante real interest rate on deposits and admitted that the demand for domestic assets is positively correlated with the expected rate of inflation. The expected rate of inflation enters to represent portfolio shdftes towards capital goods and government bonds (Indexed assets) as the expected real rate of return on money falle (8ee Tobdn (1965). S1drausk1 (1967) and Plsher (1979)!. Note that we do not distinguish the demand for capttal goods and govermment bonds because the rates of returs on botb ssets are generalis indexed in developing countries with high and variable inflation. Further desegregetion of domestic assets w11 take place in section 2. We defined the expected sate of returm on foreign assets as the foreign real interest rate and the expected rate of depreciation of the local currency. In order to take lnto account the existence of liquidity constraints on portfollo's decisions, the variations in bank credits to the privare aector $\left(L_{p}\right)$ and in foreign capital laslows $\left(D_{p}\right)$ havs been introduced lnto the model. An increase in real credit of in forelgn financing will in general encourage the acquisition of assets since the economic egents are limited by the ovallabditity of their current resources.

The expected 8 igas for the parameters of equation (4) are sumpardzed is table $\mathrm{l}$. Bach rate of return influences positively the

6/A oimllar model has been presented in more derallo in Mordsset (2999).

7/The decision berween present consumption and future consumption does not seem to be igniflcanty influenced by tho real rate of Interest in mose developing countrles (e.g. Glovannind (1983) or thatkhate (1988)). 
asset to which it is assoclated and negatdvely others asset88/. We also asoume that an Increase in GDP level ralses the demand For money (rransactson motive) and decreases the demand for forolgn assers (soe Coness (1986)). In the presence of borrowing constrelste, one Incresse

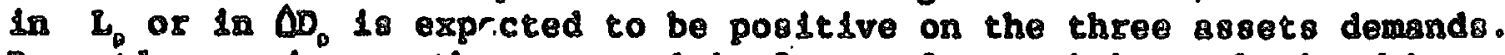

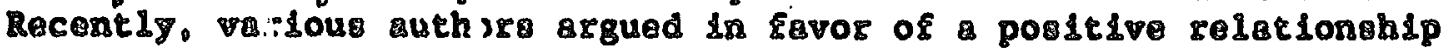
between the vartarion in grose externel debt and capltal flight (0.8. Cuddington ; i987)) and Le88ard and Filliamson (1987)).

In view of the budget constralat (1) de lo clear that the three asset demand functlons are linearly dependant. Once an agent has determined his holdings of any two sesets glven the level of the rebcurces available to him. his demand for the third arset has impliedely been decermined 88 well. Thus the following restrictions must hold?

$$
\begin{array}{ll}
\text { (5a) } a_{2 j}+a_{2 j}+a_{3 j}=0 & \text { with } j=1,2,3,4 \text { and } 7 \\
\text { (5b) } a_{2 j}+a_{2 j}+a_{3 j}=1 & \text { with } j=5 \text { and } 6
\end{array}
$$

Hence equetions (4) ase linearly dependant and one equarion must be omitted for the eseimstion of the model.

The model (1)-(4) is similag to the one presented by Tobin (1965) in the sense that an incresse in the demand for financisl savings sollowing high renl interest rates on deposirs will generally lead to a reduction in domestic assets demands. This portfollo shift represents the lasger attractiveness of holding money than productive capital and public bonds. However, this approsch fallo to take into account the McKinnon-Shaw hyporhesis which assunes o positive relationship between the demand for money and tho demand for capital accumulation via tho domertc credito to the private sector extended by tho banking ojstem. This positive Iink between morey demand and real lnvestment may bo e8sily istroduced into the model through the resl budget constralat of the financial sector. The banking system, which is asaumed to integrate the contral bank and combarclal banks, accumslates reserves, extends credit to the government and the private oector, and 188ues 1iablittes in the Eorm of money:

$$
\left(\Delta \mathrm{L}_{0} / 8\right)=\Delta \mathrm{Dat}-(\Delta R / B)-\left(\Delta \mathrm{L}_{8} / \mathrm{B}\right)+\Delta \mathrm{An}
$$

where the real banking system net profit (Anw) is defined as the difference between gecolpts and outlays, 1.0. Lnterest recelved minus interest pald plus other net non-1nterest income minus operatisg expenses, corrected by the changer in domertic infletion and exchange rategel.

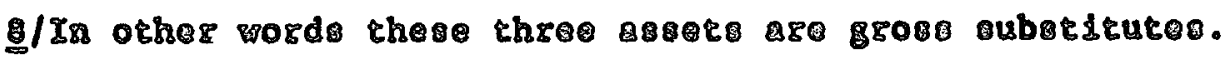

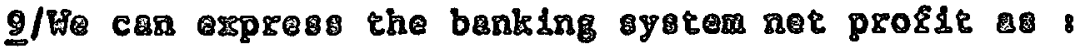


Equation (6) Indicater that a rise in money demand muse cause. cereris paribus. an Increase in the oupply of credit to the private sector odnce domestic credst 18 the primary esect becking the monetary Ldablidedes of the banking eystem. Moreover, this presentation also emphasizes that the amount of crodit to the private sector is not directly controlled by the Einancied oector in most developing countries. Blrat. controls on credit to the private sector have been the principal instruments of the monetery policy and, second, the amount of credit to the public sector hes been usually derermined by the demand of the government gather than the supply of the Elnanclal systemlo/.

Introducing (6) into the syotem (1)-(4), we can reconc1le the Tobin' arguments and the McRinnon-Show hypothes18. In e finencial liberalization program, the real rate of intereat on deposite and lending rates are in general both decontrolled. The vagiation in the deposte Interest rate should encourage Elnancial satings accumulation whlle the vartation in lending retes should aseure positive proflts by the banking sysiem. Note, however, that the variation in leading rates does not affect directly assets demands because, under ratlondng, the cost of credit is not an argument of the private sector's portfollo behavior. The total impact of ardation in real incerest rates on the demand for domestic asets 1811 /:

$$
\frac{d(\Delta h)}{d r}-Q_{28}+\frac{Q_{28} Q_{28}}{\left(1-Q_{16}\right)}>\text { or }<0
$$

The flrst term corresponds to the substitution effect suggested by gobin and the second term to the positive offect postulated by Mckinnon and Shav. A veriation (8ay an increase) in the real interear rate changes the asset portfollo as assetholders move out of real savings and forelgn assets into domestic money. On the other hand, the 8180 ln money demand incresses the supply of domestic credite to the private sector and private investment ince the private sector fis assumed to bo liquiddry congtrained. The cotal lmpace of a change in the interest rate

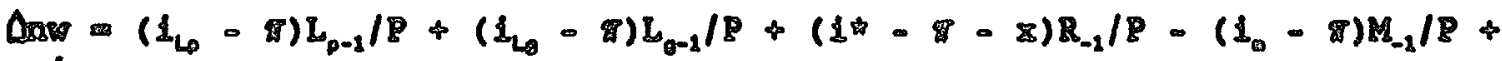
nd

where $1_{4}$ is defined as the nominal lending interest rate to the private sector, $1_{L}$ as the nominsl lending interest rate to the public oector,

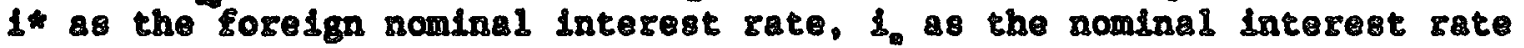
on deposits. nd as other net non-inesrest income, as the infiarion rate. Pas price level and $x$ as the rate of deprectetion of the local. cusserscy.

10/800 seçtion \& for a more grec180 discussion on this romark.

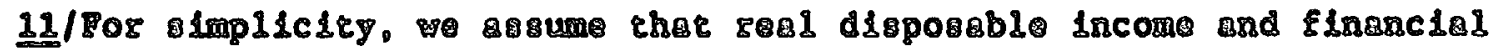

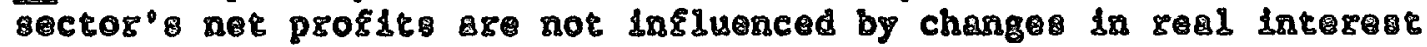
rocer is aquerton (7). Higher borsowing and leading racer should affect these tro pariable In opposite directions so thet the toral affect should be weok. 
depende on whether the Incresse in donestsc credite due to the Mcrinnon. Shaw offect exceeds or not the reduction in tho demand for capical goodo duo to to tho portêd10 ahsft. Note that this approsch does not cake Into eccount the, eventusl decine in excesolve lsventordes when firms can lavest La en aternative domestic financial asoets. If inventories

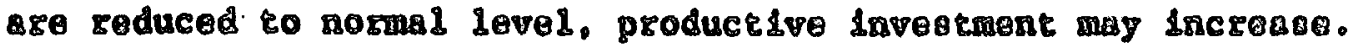

The upahot of all this to thot one cannot prediet the dmplication of changes in real deposite 80608 whout heving some ingight in the Elnanedal etructure of the economy. Specificelly, one wanes to know which s8set is the closest gubsedtute to bank deposdte (1.e the cosfficients $\alpha_{23}, a_{23}$ and implicitly $\alpha_{83}$ ) and whether the banking system w11l be allcwed to play 1ts intermediary role or not (1.e the coefficiente $\alpha_{10}, \alpha_{28}$ and implicitly $\left.\alpha_{30}\right)$. In that sense, financial liberalization program may directiy Improve the allocation of domestic credit to the extent that, with positive real interest rates. credit would be allocated according to expected productivity rather than transaction costs and percelved risks of default (see Mckinson (1973)). since financial liberalization policies may involve changes not only in tho quantity of investment but also in the quslity, we will dicuse more precisely on this polnt in the emplrical part of the paper (see section 4).

\section{The Plexdble Acceleratcr Model of Investment}

The approsch presented in section 1 clesgly stresses the substitution effects generared by changes in Interest rates on assets markets. The portfollo model owes much to the ploneering work of Van Wijnbergen (1983) even if the portfollo sh1ft lnto bank deposits is coming out from real savlags ingtead of the "curb market" se suggested by this author. Because the majority of the authors tho atrempt to study the relarionship between real interest rates and real private invertment in LDCs has viewed Invertment only as the demend for capital goods by the users of capital services, we introduce into the analysis this second sepect (e.g. Blefer and Khan (1984), Bry (1980) and Tun Wad and Wong (1982)).

The denand for capital serolces is usually derived from an sdapted version of the flexible accelerator model. This approach emphasizes the effects of the resources constraints faced by prdvate investors in accordence with the McRinnon-Shaw view. In the long-run representation of the accelerator model. the desdred stock of capital (k*) that the private sector wishes to have in piace can be assumed to be proportional to expected output ( $\left.y^{*}\right)$ :

(8) $k *_{0}=9$

Th1s 18 a qute standard formulation in which the underlying production function hes (rechnologicaldy) flssed proportions among 
factors Lnputs 80 that Eactor pgleos do not ontor dnto tho

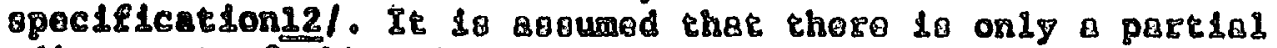

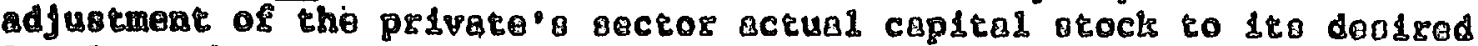
level bo that we can wisteo 8

(9) $O k_{p}-B\left(k t_{p}-\left(k_{p-1}\right)\right.$

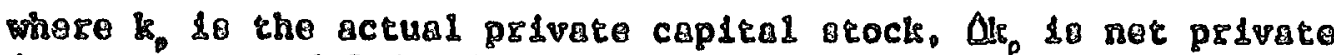

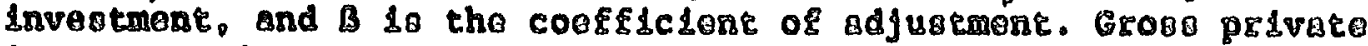
Invertment 10 made up of two componente - net inveorment and replacement. Net Inverement gesules from chenges in the desdred orocts of capital. whdle replacement 18 here osoumed alwayo to bo a frocelon of of the capitel atock on hand at the bogdining of the perdod :

(10) $\perp_{p}=\Delta k_{p}+O k_{p-8}$

We then gubsticute equations (8) and (9) Into equarion (10). and we get the following dnvestment function for the privere sector:

$$
\text { (11) } 1_{0} \equiv B B y^{w}-(B-O) k_{p-1}
$$

In order to take into account the essistence of Ilquidity constrainte, the speed of adjustment between desiged and actual privare capitel stock (B) 18 assumed to vary systematically with the avilability of internal funds, bank credite and forelgn captial inflows. Ilnesr representation of this relationship is :

$$
B=B_{0}+\frac{\left(B_{1} c E+B_{2}\left(\Delta L_{p} / P\right)+B_{g}\left(\Delta D_{p} / P\right)\right.}{\left(k \psi_{p}-k_{p-1}\right)} \text { with } B_{1}>01 \approx 1,2 \text { and } 3
$$

where $c$ is defined se frmo' cosh flow: measure of internal funds avaliable for financing private investment.

Equation (12) states that the speed of adjustment is influenced positively by the total financing available to the privare sector measured in relative terms with respect to the size of the discrepancy bet een desired and actus private capital stock. Note that if the signs of the parameters in equation (12) are all expected to be positive the Impact of the three alternative sources of financing on the speed of adjustment 18 not assumed to ba equal. As bank credits depend on the Elow supply extended by the financial sector rather than the demand of private investors, a firm's investment decision is independent of tis Einoncial condition. Recenty, Pazzar1, Hubbard and Perersen (1988) demonstrated that Internal and - remsi resources aro not perfect substitutes in a firm with liquidity constraints.

12/ Using an alternative production function, the desired capital stock level could be also influenced negatively by the rental price of capital. Thile this specification may complicated the empirical implaneretion of the model - such variable cannor be easily calculared for developing countries, it does not change significantly the results presented here. 
Fstally. auboticuting equation (12) sneo oquation (11), we obtain tho following privare Invootment Euncelon:

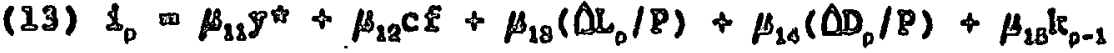

$$
\begin{aligned}
& \text { wich } \beta_{1 \Omega}=B_{0}>0 \quad \mu_{2 \Delta} \square B_{9}>0 \\
& \beta_{2 B}=B_{2}>0 \quad B_{2 B}=B-B_{0} \\
& \beta_{18} \boxplus B_{2}>0
\end{aligned}
$$

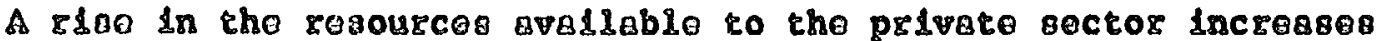
the opeed of adjuscment oo that ald paramerers in equation (13) could a prdord be determined posdtive. If wo incorporete this equation into the portfollo model presented in section 2. the effect of an lacrease in real intereat rates on private investmant appears to be unambiguously positdvel3/:

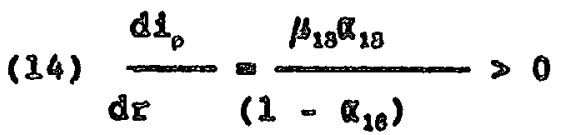

The general concluston to that an increase to the real rate of

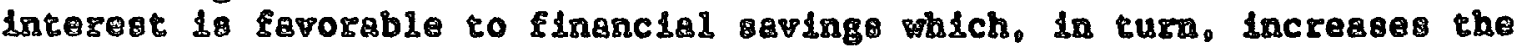

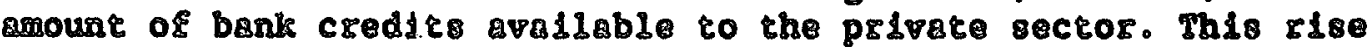
Influences postrively the speed of adjustment between desired and actual private copital otock and, hence, private davestment. But this prosenterdon provider a misleading and lnconclusive plcture of effectuenes of interest policies. In parescular. the introduction of the public sector lnto tho anslygis mag affect dramstcelly the former regule olnce the government can absorb part of the regources made avadiablo for privato invoriment. The rest Bection 18 devoted to the demonstration of this crowding our effect.

\section{The Introduction of the Public Sector}

The experdence of the last decade indsceres that most LDC governent Einanced their fiscal deflcit with credits from the central bente. Although these governments could concedvably experiment with this sousce of Einancing if it were an independenty controllable variable. Le would generglly be mose reallstic to trest additional borrowing from the cencsel bank " 8 a consequence of \$l8cel disequildbrium of of the Inobilitg or unw111 Ingnes to finance the growth of exhaustive goverment expendikure, guboldies, and transers through expliclt taxes

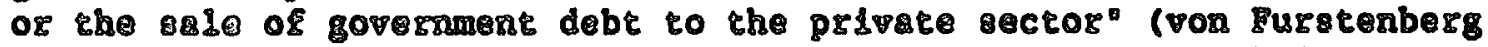
(1983. p.233)). Foldowlag this remsts the demand of the public sector for ceneral bank credite can be opectsted 88

$$
\Delta \mathrm{b}_{0} / \mathrm{P}=\mathrm{de \varepsilon} \varepsilon_{0}-\Delta \mathrm{b}-\Delta \mathrm{D}_{\mathrm{g}} / \mathrm{P}
$$

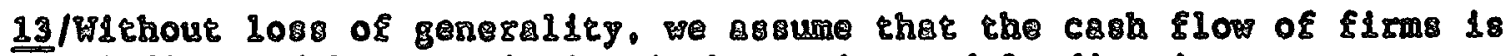
not LnElunced by a vardacton in borsowing and lending incerest rater becerse tho Impect of such regiation do difficule to prodict. 
wore def do defined as the total flecal deficlt14/. Ob as the raleo of publdc bonds to the private sector, LofR as tbe changes in domestic crodlts to the government extended by the banking aystem and $D_{8} / 8$ s8 the vordaclons in gros8. public external debe. Egustion (13) emphesizes that mo\&t LDC goverament have financed theds deficle rolh central bank credits when they cannot use other sources of flnencing. Indeed. In many dovelopdag countrie financing the public doficdt in the forelgn and domeselc credit mastete becomes 108 seselblo over time beceuse the declining credibility of the public sector.

The authordeles can odmindacer the bonds war it by two different Instruments: Interest rates celdinge and controlo on the flow oupply of bonds. If either the interest rate on public bonds or the flow supply of bonds 18 trested as an erogenous verisble. the other become endogenous. With the Interest rate exogenous. the government chooser to fix legal cellings on the lnterest rate on public bonds. In this case. the quaneley of bonds 18 only determined by the bonds demand of the private 8ect0r. Alternatively, the government can choose the amount of bonds exogenousig and the public bonds market adjusts through a vardation in the Interest rate on bonds. Let us assume that the Interest rate on public bonds is fixed and that the quantity of public bonds 18 determined by the privare sector 8 willingness to hold public bonds. Erom oquation (3). the demand of the privare rector for pubilc bonds 18 equel to :

(16) $\Delta b=\Delta b-10$

The presence of the public sector can alker tae positive effect of flnanclal ldberallarton on domestic crediro and hence on prifete Lavestment. Introducing equetdons (15) and (26) Lnto the model, the

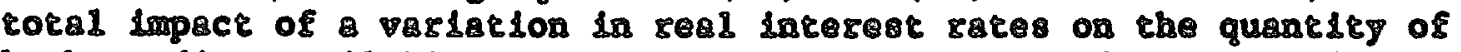
bant crodles avallable to the privare sector is the followdagls/ \&

14/The totel flscal deflcit can be expressed as 8

$\operatorname{def}_{\theta}=\left[L_{0}+g-[]+\left(L_{0}-g\right) B_{-1} / P+\left(L_{L_{0}}-\mathbb{T}\right) L_{0-1} / P+(1+-2) D_{0-1} / P\right.$

where if 18 the nominel interest rate on public bonds. Lo the nominel lending rate on domestic credit to the public sector. 1t the forelgr nominal Interest rate, $1_{0}$ public invertment, 8 public current expenditures. net rases. B $B_{-1}$ the nominal gtocts of public bonde in the beglnning of perdod, $L_{g-s}$ the nominel stock of domerts credtt to the public sector. $D_{a-1}$ the nominal stock of public external debt and $B$ price level.

15/Again, for oloplificarion, wo sarume that vardation in interobr

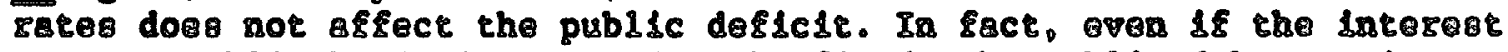
rate on public bonds 18 assumed to be slxod, the public debt-80rvice payments will 1ncresse through the change in landing roter 80 that the crowdiag out of domertc credte to the prdvate sector 18 stronger than suggerted in (17). 
(17) $\frac{d\left(\Delta Z_{B} / B\right)}{d r}=\frac{\left(Q_{18}+Q_{28}\right)}{\left(1-Q_{18}-Q_{23}+\mu_{18}\right)}-\frac{\left(Q_{18}+Q_{28}\right)}{\left(Q_{38}+\mu_{18}\right)}>$ or $<0$

The cotal impact of an increese in the real Interest rate on bents credits arollable to the private sector cannot be prlori derernined in multipller (17). As suggested by McRinnon and Shaw, rlse in the robl rate of interest increases the demand for national Iiquidirses and. therefore, the quantity of bank credits. But, the incroduction of the pub11c Bector Into the anelysis shedo 11ght on an important chennel through which crowding out of domestic credite to the priflete sector occurs in many developing countrles. The finencial gerorm may ersecerbare the demand of the public sector for bank credits and, thereby, limiting the funds avoliable to the private sector. It 1s noteworthy thet the specification chosen here suggests thet the crowding out does not come from a change in the government behaviog, but Eron a shfe in tho portfollo of private agents. As demands for moneg and caplesl goods incresse, the private sector's willingness to purchase government bonds 18 reduced, constraining the public sector to finance lts deficit with more credits from the central bank16/.

Incerestingly, the crowding out effect does not appess very sensitive to changes in different sources of financing of the flocal deficit. In order to prevent the diversion of domestic credit to the public sector following increase in interest rares on bank depostis. the government may be atrracted to increase simulraneously the iaterest rete on public bonds or. If the lnterest lo endogenous, to ralse the slow supply of bonds. In this cese, the crowding out of domestsc credit to the privare sector w111 not come from tho portfollo shife from domestic bonds into monetseg assets. but from the incresse in the public debe service on domestic debr17/. SLmilarly, the authorieles may atrempt to increase the rate of inflation - an usual source of financing

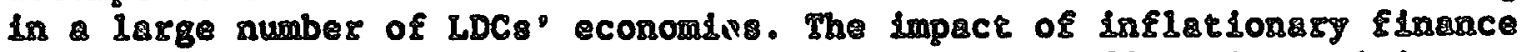
os bank credit remsins ambiguous. On one hand. the effect is positivo through the lncresse in public bonds demand (indessed sssets) and the reduction in the public debt-service but, on the other hand, the effect Is negative through the decilne in mones demand18/.

16/ The ame argument wer used decade ago by varfous authors in ordes to jusesfy Lreerest conrgols in LDCs (e.g. Nicols (1974) and Polals (1989)). These athors ouggested that 85 the rate of interest on bask deposits 18 kept low, Lnvestors lack an artroctive alresnative to investing in government peper.

17/An Incresse in the intorest rote on public bonde ralses the debt 8ervice of the domertic debt and. therefore. the public derscit.

18/08 courbe, this discussion on the effect of vartarion in the rete of inflarion ds tentarive because inslardon 18 ereared as arogenous

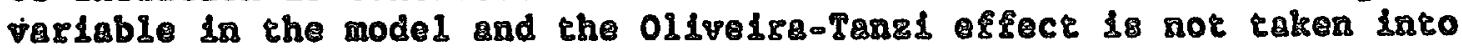
accourte. 
Uodng equarion (17), we can successively define the shozt-run rotel offect of a change in real inerrest rater on the demand for domestic aosers and private lnveriment 8

(18) $\frac{d Q b}{d 8}-Q_{23}+\frac{Q_{28}\left(Q_{13}+Q_{23}\right)}{\left(Q_{28}+\beta_{18}\right)} \quad$ OS $<0$

$$
\frac{d d_{0}}{d x}=\frac{\mu_{18}\left(\mathbb{R}_{28}+\mathbb{Q}_{28}\right)}{\left(\mathbb{Q}_{28}+\mu_{28}\right)} \quad \text { or }<0
$$

Equations (18) and (19) ouggest that the fifect of financial Iiberaldzation cennot be prlori determined on domertic asseto demand and private Investment.

In sumary, the complete model conster of three behevloral 58lationships - equarion (48), (4b) and (13) - and four rechnical relatlonships - equations (1), (6), (15) and (26). Together these seven

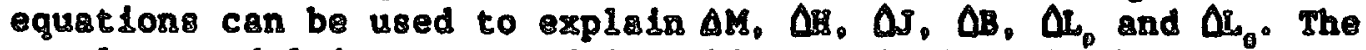
complete model 18 presented in Table 2. Within this framework. we address the critical issue of whether the positive effect ouggeated by Mcifianon and Shas is strong enough to offset the crowding out of domertic credits and the shift from real savings into monetsing asete that could occur in the portfollo of the privete sector.

\section{As Empirical Test: the Case of Argenting (1961-82)}

The model developed in the last section could be used in principle to examise the short-rus effect of a variety of shocks on private Laverrment and other endogenous variables of the model. By estimsting the model for Argenting and by stimulating 1t. the response of key vardables to changer in real reter of interest 111 be derlved for this counery.

The data on $S_{p}, Y, \Delta, Y_{,}, I *$. and $\Delta R$ have been obtadred from the - Internationsl Monetary fund International Financial statistics. Serdes from the Horld Bank (1985) and the Central Bank of Argentins have 180 been used EOS I 19/. All varlables have been deflated by the wolesele price index $(1974-100)$. The data on private wealth stock $\left(W_{R-1}\right)$ have been constructed by cumulatively adding the time serdes on private savings. stnce Ilnesr functions are used. the error in estimeting the initial rodeb orock can be readily absosbed lnto the latercept cerm. The not profle of the banking sector ( $\mathrm{nw}$ ) hes been calculated as the residurd of the financial oystem budget constgadnt20/. While we attempted to

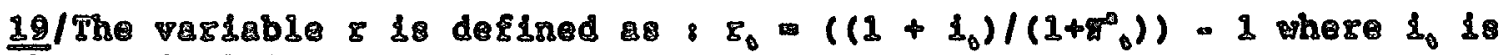
tho noninal Leresere rare.

$20 / \Delta$ nos $m\left(\Delta L_{D} / P\right)-\Delta+(\Delta R / B)+\left(\Delta L_{\theta} / P\right)$ 
measure the expectod rate of Inflatdon (40) usdng tho adaptatyve and

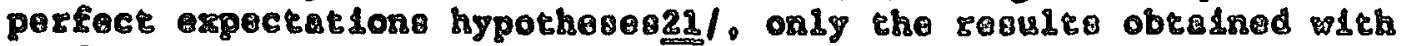
perfocr axpectations aro presented in thdo papor. Perfoct forealght

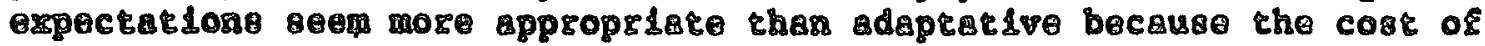
Ignoging the future offect of curgent pollcy actions can be gudte high

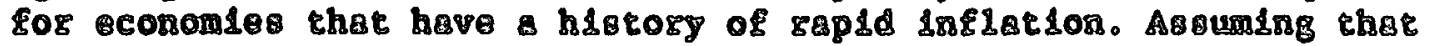
economic agents refer to domestle cond1elone rather then to the roredgn real Interest rate, wo defined the expocted rate of goturs on fosodgr assets only with the rate of inflation. Dats limitation enforced us to approximate the finms ${ }^{\circ} \mathrm{Cs}$ sh flow wh the difference between potentsid Bnd effectdve levels of production 88 mersurod by tho Whsgton Inders (INDF). He assume that the enterprises could respond more as811y to changes in desired investment when demand condttlons are buojant. Finally, in order to improve the epecification of the model. we incroduced lnto equations (4) an indicator of unceresines about Inflation (VE) measured as the variation of the rate of inflationz2/ and we incorporated public investment $\left(1_{0}\right)$ lato the private investment function (13) as suggested by various authors23/.

In table 2 we report three-atage Least-Squares (3SLS) estimates for Argentina over the 1961-82 period. On the whole, the resulte are quite arisfactory. The explanatory power $\left(\bar{R}^{2}\right)$ and $D$ W are both acceptable. suggesting a good specificetion of the model. The nost interesting aspect of these resulte concern the resl gates of interest. Indeed, the estimated coefficiente for 8 appear to be positive on Elnanclal savings (daM/dr $=3.672$ ) and negative on real savinge (dats/dr $=-1.234$ ) and copital flight ( $20 \mathrm{~J} / \mathrm{dr}=-2.438$ ). These results seen to be quite compatible with the Argentine experience, e.8. World Bank (1985). For instance, the deregulation of interest rates 181977 resulted in a further increase in real interest for deposits and thus there was a dramatic Increase of 8 avings through the banking 8ystem. Our estingres ouggest that the buildup of deposits was backed by repatsiation of capleal Inverted abrosd and by decressing demand for public bonds and capltal goods. In short, an increase in the resl rates of interest involved a portfollo shife from capital goods and foreign ossets into monetary domestic assets. Howerer, these estimates include only the direct effects of a rise in interest rates and, therefore, they cannot be interpreted as the toral effect of such increase (see below for further explanations).

Also of relevance 18 whether the banking system has played its incermedisty gole or not. The estimated impact of a yoristion in flow oupply of credit $\left(\Delta L_{p}\right)$ on private investment $\left(d L_{p} / d\left(\Delta t_{p} / P\right)=0.258\right)$

21/Th18 reflects the fact that. 1though sational forecasts could differ from ectusl price movements in stochastic models, rationsl expectations are equivalent to perfec: foresight in determialatic models.

22/seo Blejer (1979) and Gupta (1984).

23/For Instance, see Blejer and than (1984) and Sundararajen and Thekur (1980). 


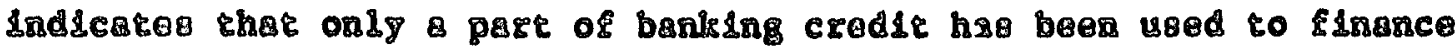

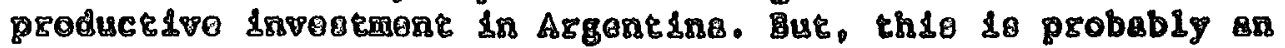

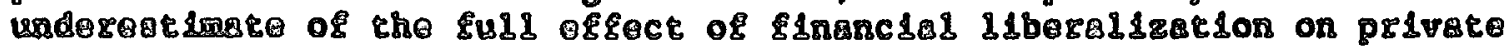

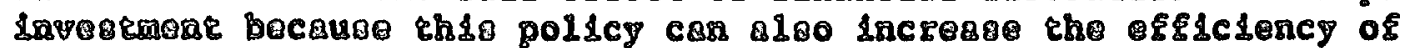

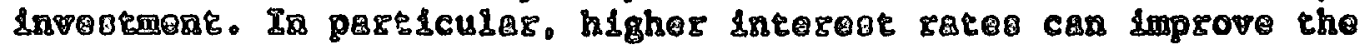

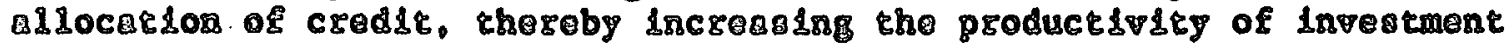

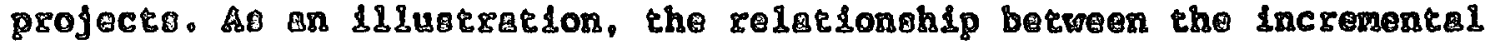

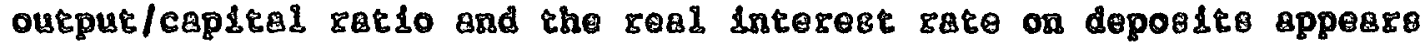
posdestre and 8Igndficant in the cBse of Argentins24/. This ouggests

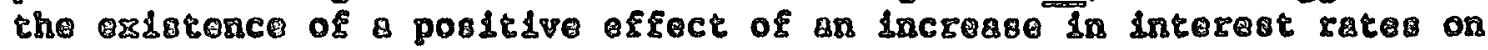
the qualdity of 1suestment25/.

The gerultr pertalning to the other varlables also deserve brief

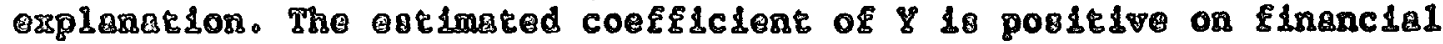

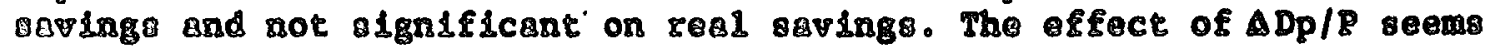
to bo positive on finsncial savings and negative on real savings. As equarsons ine Inearly dependent, we able to deduct that an incresse in escras debe led to capleal flight durdng the $1961-82$ pertod in Argentine $\left(d G J /\left(d d D_{0} / P\right) \approx 0.445\right)$. This positive correletion could be expleined from the liquidity effect. corruption and policieo which - imstraseousely promoted foreign borrowing and capital flight, 0.8 overtaluerdon of the local currency. The positlve reletionship between the flow supply of credit $\left(\Delta \mathrm{L}_{\mathrm{p}} / \mathrm{P}\right)$ and the demands for Elnanclal savinge

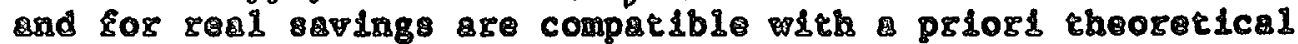
expectarion since the Argentinean private oector han bees liquidity cosersatned. The espected rete of daflation $\left(\mathbb{F}_{0}\right)$ seens to have exerted a positfwe effect on Financial and real obulngs. Hith respect to resl saydnge, this result cossesponds to the one predicted by the theoretical analysis and, with respect to finsncial sevinge, it could be expleined by the fact that banking deposits (In particular short term deposits) have been indered in periods of high and varlablo inflation. The negardve effects of $\mathrm{VE}$ on domestic assers demand and money demand confirm that uncertalnty about inflation has increased capital flight. Finslly. the estimation of the real private invastment function seems to be Batdifactory since 211 parameters have the expected 81 gns, ercept the variables $k_{p-1}, Y_{-1}$ and $\left(\Delta D_{p} / P\right)$ whose effeck do not appear significant. Nore that public investment has a positive effect on privare investnent. suggesting that complementary relationships between both lnvestment categordes dominato in Argentina.

Dynamic simularions (1.e. lagged variables are those generated by the model (trelf) show that the goodness-of-fit of the model as whole 18 Beirfylag Sor Argenelns over the $1961-82$ pertod. Table 3 provides

$24 /$ to ussd the procedure proposed by Fry (2988) and Gelb (1989). The estionted coefficient for Argentine is equal to 1.206 on the 1961-82 period.

25/gorgever, beyond the lnterest rates level, lmportant factors such as the high degree of interlocking omershlp and control that existed, and that continues to extst, berween industrial flrms and financial institurions may jeopardize financial liberaldzation policies in Argering. 


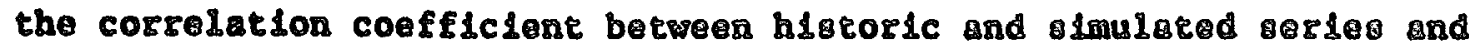
Thel1'B inequality coefficlent for the endogenous vardebles. If ehese coofictent Indicate that the small structural model is stable and are Indicative of lts robustness, neediess to say, that our olmulation resulte have to be vlewed with ome care. Actually. they are incended

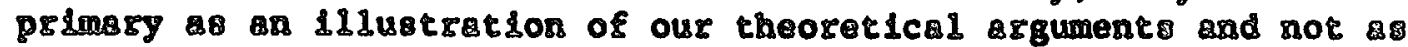
perfect representation of the Argentinean economy.

The model could be used 8 bests for dertolng the short-run torel reaponse of private investment to an Incresse in real sotes of interest. Since the model is linear. the imulations results are independent of the starting conditions and, moreover, they are qualitatively independent of the absolute size of the shock. In Table 4 we report the total short-rus elasticity of the maln endogenous varlables of the model to one percentage point increase in the real sete of integest. Ous simulation results indicate that real private investment 1s littlo responsive to interest changes $\left(d i_{p} / d r \neq-0.047\right)$, but this is not ourprising olnce it reflects the presence of many opposing forces allowed for by the model. The total interest insensitivity of private Investment is largely due to the portfollo ohift from capital goods Lnto financial savings. On one hand, the increase is monetary 11 ablitties lo favorable to privete investment vis the domestic credit market as suggerted by McRinnon and Shaw. On the other hand. this portfollo shift undermines the private sector's wlilingness to hold capltel goods and government bonds ( $\mathrm{d} b / \mathrm{dr}=-0.459$ ). This last effect lmplies that the Elnancing of the public deficit in the domestic credit market become 1088 feselble and credits from the banking oysten must bo used to Elnance part of the deficit ( $\left.\mathrm{L}_{0} / \mathrm{dr}=0.376\right)$. In ordes to offset the expansionary effect of large domserdc credite to the public sector on money supply. the monetery autboritles heve to keep credits to the private oector under strict control. As consequence, the resuledng changes in private real investment depend criticaliy on whether the

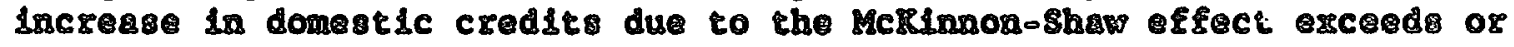
5alls short of the reduction in domsetsc credses due to the crowding out effect. Empirical resulte seem to Indicate that for Argentins the negative effect 18 highes than the positdve effect (d $\mathrm{L}_{0} / \mathrm{d}$ s $=-0.284$ ) 80 that the total effect of financlal liberallzation 18 weak (even negarive) on privare invertment.

\section{Concludlag remarks}

The purpose of this paper has been to demonsesate ofleh a smple otructural model that a number of factor can Influence the relationship between real Interest rates and private investment in LDC8. Ho emphasized on two specific problems. Plrst, we polnted out thet the positive effect of a rise in domeotic credit as suggested by McRinnon and Shaw could be offret by a portello shift from caplesl goods lreo monetary aretr. Second, we demonstrated that financial

ILberalizstion policy could Increase the demand of the public sector for

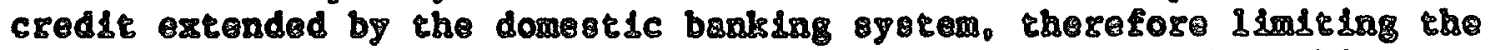
funds crallable to the prdvate sector. It 88 soteworthy that this crowding out effect does not resule fron a change La the government's behavdor, but rather from ohdft in the portfoldo of pgdvere agents. 
Hgher demand for bank deposits reduces the private sectos ${ }^{\circ}$ erdilingneso to hold govesment bonds so thet the public sector is required to flnance glven budget deficit with larger amount of domestic credit. While the model has bean estimsted for Argentins, it is quite apparent thet tble epeciflcarion cen be readily epplied to other devoloping countr1e日 as we11. The general conclusion that emerges 18 that the offect of interest retes polictes on the demand for capital goods is weats in the case of Argentine, albelt the toral impact might be sironger on the quality of investment then on the quantity26/. The absence of any rerong relationship berween resl interest rates and the quantigy of dnyesment does not result Erom excoedingly small direct interest elasticities of prtubte Investment. Insterd. It is due to the interact dons of a number of mechansems allowed for by the model which rend to neutrollze the impact of such policies.

Although the model used in this paper could be improved in asy was9. B.g. Infiaition should be endogenous and it 18 very unlikely that real Interest rate policies can be considered as exogenous even if it rater are controlled rather than market-determined (e.g. Galb (1989)), the policy implications of the exercise are straightforward. The incresse in real interest rates, which is typical element of strancial reforms. do not necessarily involve posirdve effect on privare investment unless the outhoritses are careful to ensure thes : (1) Bank deposits are closer substitures to unproductive asers (cosh. gold) and forolgn assets racher than to capiesl goods?

(2) The EInancial sector assures an efficient dlocerton of domeric cred1ter:

(3) The flow of domseic credit to the pglvere sector is not absorbed by the nead of the public sector.

\section{BIBLIOGRAPHY:}

M. BLEJER, "The Demand for Money and the Vardability of the Rate of Inflat jon \& some Empirical Results", Ineemertonal Economic Revien, 20. juse 1979

M. BLEJER T. TANZI, Infletion, Interest Race Pollcy and Currency Substitution in Developing Economses D Discussion of some Mojors I8sue ". World Developmenc. Fol.10, n.9, sept. 1982

M. BLEJER M. KaAN, "Governent Policy and Privato Investment in

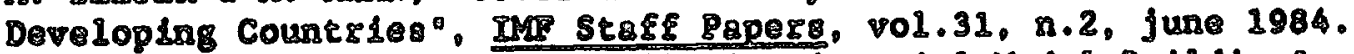
C. BRAIRARD \& J. TOBIN, "PIESQIIs in FInancial Model Budlding". American Economic Roviow, 1968

E. CONESA. The Causes of Capiral F11ghr Fron Latia America". Heshington D.C8 Inter-Amer dcan Development Bank, working paper. 1986.

R CUMBY \& LEVICi, "On the Definition and Magnitude of Recont Capied

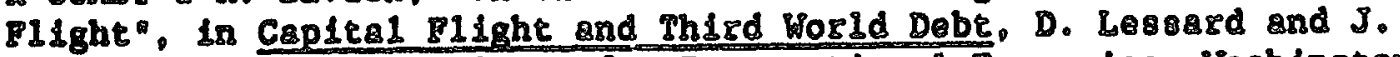

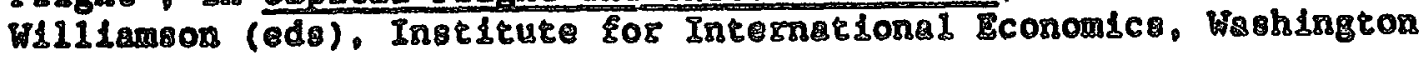
D.C.. 1987

$26 /$ Ie could be cleasiy of Intorest in some fururo work to ertend tho axalysio in thio direction. 


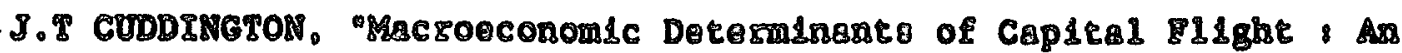

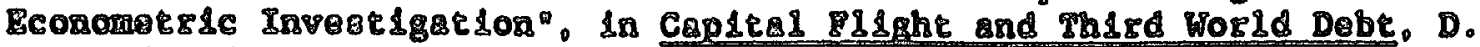

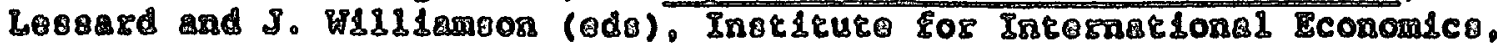
HBobingros D.G.0.1987

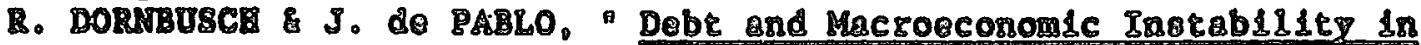

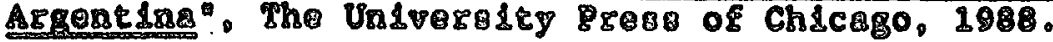

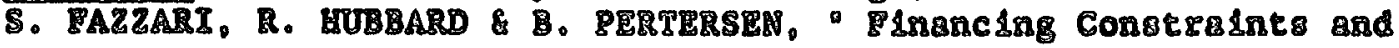

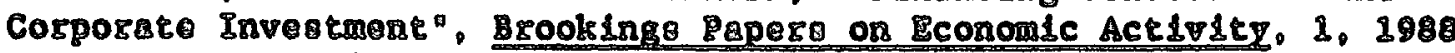
5. SISCER, "Ant icdpet Jone and the Nonneutrelity of Money" sournel of Pol1t1681 Economy, vol.87.n.2, Bpr\$1 1979.

K. FRY. "Sevings. Invertment, Growth and the Cost of PInsncial

Repres8 10n". World Development. vol.8. 1980.

M. FRY. "Moner, Intorest, and Banising in Economic Development". The John Hoplstne UnIversity Pres, 1988.

A. GELB, "Inanciol Bolicles, Growth, and EEflciency". World Bank working Paper8, 202, june 1989.

A. GTOVANINI. "The Interes Elarticity of Savings In Developing Countries: the Ex18EIng Evidence", World Development, vol.11,n.7, 1983 K.L. GUPTA. "Isance and Economic Growth Is Devoloping Countries". Croom HeIm, London 1984.

N. U. HAQUE, "Flscal Policy and Private Secror Saving Behaydor in Developing Countries". IMF Staff Papers, vol.35, n.2. June 1988

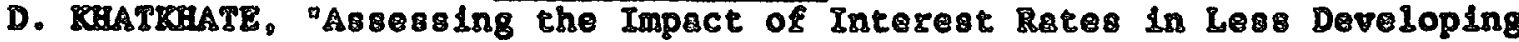
Countr1e8 $\%$, Hor1d Development. vol.16,n.5,1988

R. MCIIMON, "Money and Capital in Economic Development". Heshiagton D.C. Brookings Institution, 1973 .

B. MONTEL. "Cred1r and Flacel Policies in a Global Monecarsst Model of the Balence of Payments". IMP Seaff Papers, vol.31,n.4, october 1984 3. MORISSET. "L' a fectation du financement externo dano un pays en vole de developpements un modele de portefeullie". Revue d"Economie Bolltique, juiller-8out 1989.

D. NICEOLs. "Some Principles of Inflarionery Pinance", Journal of Pollelcel Economy, n.2, maxchoepril 1974.

J.J. POLAR, "Binancial Policles and Development". Center for Developmene, OECD, paris, 1989 .

D. BURVIS, "Dynamic Models of Porefollo Behavior: more Plefallo in Binancial Model Bulldings". American Economlc Review, LXVIII(3), 1978. T. SRAF, "Inancial Deepening in Economic Development". New Yosk, Oxford Universiry Press, 1973.

M. SIDRAUSRI. "Rational Cholce and Parterns of Growth in Monetary Economy". American Economic Review, vol.57, n.2, msy 1967.

S. SUNDARARAJAN, "Debt-Equity Rat10 of Firms and the Effectiveness of Interest Rere Poldcy : Analysis with a Dynamic Model of Savings. Invertment and Growth In Rorea", IMP StafE Bapers, rol. 34, n.2, june 1987.

S. SUNDARARAJAN \& S. THaKUR, "Public Investment, Crowding Out, and Grouth: A Dynamic Model Applied to India and Korea", Im Staff Papera. vol.27, n.4, december 1980 .

J. TOBIR, "Money and Economic Growth", Economergdce, 33, n.4, october 1963 .

ర. TUN WAI \& C. WONG, "Determinanto of Private InYestment in Developing Councrdes". Jousnal of Development Studies, vol.19. october 1982. 3. TY80UT, "Alrm-Level Chronicle of Financial Crisis in the Southern Cone". Joumal of Development Economics, 24, november 1986. 
8. VAN HIJNBERGEN, "Credst Pol1cy. Inflation anc Growth 18 a P1nancially Represead Economy". Sourngl of Development Bconomles. vol.13, suguar 2983.

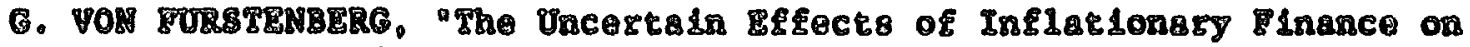
Gropth Laveloplag Counes188". Public Flnance, n.2, 1983.

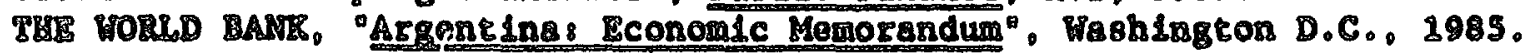


Toble 18

Expoctod Signs of the Berametero

\begin{tabular}{|c|c|c|c|c|c|c|}
\hline & $y$ & Ta & 8 & $(5+x)$ & $\Delta 0_{0} / \mathrm{s}$ & $\Delta u_{p} / E$ \\
\hline$\Delta B$ & $\mathbb{Q}_{18}>0$ & $a_{18}>0$ & $\alpha_{28}>0$ & $\mathbb{Q}_{18}<0$ & $B_{18}>0$ & $\mathbb{B}_{1 B}>0$ \\
\hline$\Delta \mathrm{s}$ & $a_{21}>0$ & $a_{a}>0$ & $\alpha_{23}<0$ & $a_{34}<0$ & $\alpha_{2 \beta}>0$ & $a_{z \theta}>0$ \\
\hline$\Delta \mathfrak{J}$ & $\mathbb{B}_{82} \mathbb{P}$ & $a_{82}>0$ & $\mathbb{B}_{\mathrm{gg}}<0$ & $\mathbb{Q}_{24} 20$ & $8 x>0$ & $B_{28}>0$ \\
\hline
\end{tabular}

Table 2 \&

Estimater of the Model for Argentine (1961 -82)

(t-8tatistics are in parenthesis)

(4B) $0 \mathrm{~m}=0.652+0.069 y+1.012 \pi+3.678+0.6730 \mathrm{D}_{\mathrm{p}} / \mathrm{P}+$

$$
\begin{array}{llll}
(-0.36) \quad(1.79) \quad(1.96) \quad(2.94) \quad(3.47) & (1.04)
\end{array}
$$

$$
\begin{aligned}
& 0.9530 L_{p} / P=0.012 \text { wp }-1=1.238 V E \text { R2 }=0.954 \\
& \begin{array}{lll}
(5.33) & (-1.00) \quad(-4.61) \quad D=1.95
\end{array}
\end{aligned}
$$

(4b) $\Delta h=5.063+0.063 y+1.447 \pi-1.23 r=0.118 \Delta D_{p} / 8+$

$$
\begin{array}{lllll}
(4.07) & (1.75) \quad(4.67) \quad(2.02) \quad(-0.94)
\end{array}
$$

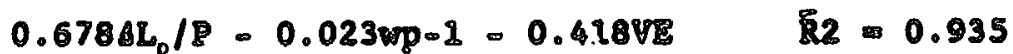

$$
\begin{aligned}
& \begin{array}{lll}
(5.98) & (-3.11) \quad(-2.63) \quad \text { DH } & -1.65
\end{array}
\end{aligned}
$$

(13) $d_{p}=-4.959-0.0159-1+9.229 \mathrm{INDW}+0.2580 L_{p} / 8=$

$$
\begin{aligned}
& \begin{array}{llll}
(-2.92) & (-0.54) \quad(3.58) \quad(4.85)
\end{array}
\end{aligned}
$$

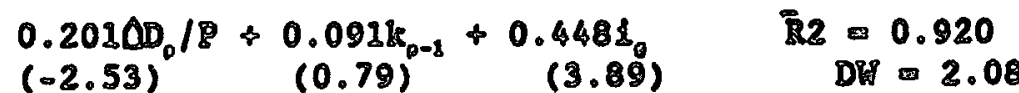

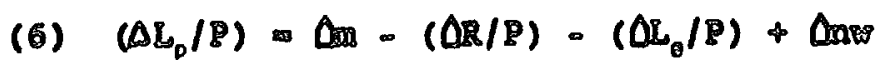

(15) $\Delta \mathrm{L}_{\theta} / P=\mathrm{def}-\Delta \mathrm{b}=\Delta \mathrm{D}_{\mathrm{g}} / \mathrm{P}$

(16) $\Delta b=\Delta b-L_{D}$ 
Table 3

Compardoon botweon lotoric and Simulared Serieo (1961-82)

\begin{tabular}{|c|c|c|}
\hline VarLable8 & correlatson coefficlont & Thedl' coofflctent \\
\hline $\begin{array}{l}\Delta \mathrm{D} \\
\Delta \mathrm{b} \\
\Delta \mathrm{J} \\
\mathrm{Ap} \\
\Delta \mathrm{Lp}_{\mathrm{p}} / \mathrm{B} \\
\mathrm{ALg} / \mathrm{B} \\
\mathrm{Ob}\end{array}$ & $\begin{array}{l}0.902 \\
0.825 \\
0.840 \\
0.780 \\
0.757 \\
0.687 \\
0.770\end{array}$ & $\begin{array}{l}0.354 \\
0.314 \\
0.466 \\
0.203 \\
0.544 \\
0.497 \\
0.532\end{array}$ \\
\hline
\end{tabular}

table 48

Direct and Total Elasticlties of the ReQl Rater of Interert

\begin{tabular}{|l|ccccccc|}
\hline Effect & $\Delta_{m}$ & $\Delta h$ & $\Delta f$ & $i_{b}$ & $\Delta \mathrm{L}_{\mathrm{p}} / \mathrm{P}$ & $\Delta \mathrm{bl}_{\mathrm{g}} / \mathrm{s}$ & $\Delta \mathrm{b}$ \\
\hline Direct & 0.204 & -0.034 & -0.372 & & & & \\
Total & -0.073 & -0.260 & 0.258 & -0.047 & -0.284 & 0.376 & -0.459 \\
\hline
\end{tabular}

1. Evrolueted ot sample moano 
WPS695 Long Term Prospects in Eastern

Vittorio Corbo

May 1991

A. Oropesa 39075

Susan Horton

Ravi Kanbur

May 1991

M. Schreier

Dipak Mazumdar 36432

Europe: The Role of External Finance Fernando Saldanha

June 1991

S. King-Watson in an Era of Change

WPS696 Macroeconomics of Public Sector Deficits: The Case of Chile

Jorge Marshall Klaus Schmidt-Hebbel

June 1991

Paul D. MCNelis

June 1991 Klaus Schmidt-Hebbel Rates to the Real Exchange Rate: Financial Liberalization in Chile, 1975-82

WPS698 Tax Policy Options to Promote

Andrew Feltenstein Private Capital Formation in Pakistan

Anwar Shah

Ralph Bradburd

WPS699 Regulation and Deregulation in David R. Ross for LDCs

WPS700 Trade Liberalization and the Transition to a Market Economy

Oleh Havrylyshyn

David Tarr

WPS701 Education and Adjustment: A Review Andrew Noss of the Literature

WPS702 Should Price Reform Proceed Gradually or in a "Big Bang?"
Sweder van Wijnbergen June 1991
June 1991

A. Bhalla 37699

June 1991

E. Madrona 37496

June 1991

June 1991

C. Cristobal 33640

M. Stroude 38831 
EBE Working Paper Series

Tine

WPS703 The Political Economy of Fiscal Policy and Inflation in Developing Countries: An Empirical Analysis

WPS704 Costs and Finance of Higher Education in Pakistan

WPS705 What Causes Differences in Achievement in Zimbabwe's Secondary Schools?

WPS706 Successful Nutrition Programs in Africa: What Makes Them Work?

WPS707 Population, Health, and Nutrition: Fiscal 1990 Sector Review
WPS708 Nongovernmental Organizations and Health Delivery in Sub-Saharan Africa

WPS709 An Empirical Macroeconomic Model for Policy Design: The Case of Chile

WPS710 Urban Property Tax Reform: Guidelines and Recommendations

WPS711 Financial Reform in Socialist Economies in Transition

WPS712 Foreign Direct Investment in Developing Countries: Patterns, Policies, and Prospects

WPS713 The Determination of Wages in Socialist Economies: Some Microfoundations

WPS714 Women in Forestry in India

WPS715 Promoting Girl's and Women's Education: Lessons from the Past

WPS716 Financing Training: Issues and Options

WPS717 Does Financial Liberalization Really Improve Private Investment in Developing Countries?
Author

Sebastian Edwards Guido Tabellini

Rosemary Bellew Joseph DeStefano

Abby Rubin Riddell

Levi Martin Nyagura

Eileen Kennedy

Population, Health, and Nutrition Division, Population and Human Resources Department

Date

Contact

tor paper

June 1991

A. Bhalla 37699

June 1991

C. Cristobal 33640

June 1991

C. Cristobal 33640

June 1991

O. Nadora 31091

June 1991

O. Ne: ra

31091

June 1991

O. Nadora

31091

June 1991

S. Jonnakuty 39074

June 1991

V. David

33734

June 1991

M. Raggambi 37657

Thomas L. Brewer

June 1991

S. King-Watson 31047

Simon Commander

June 1991

O. Del Cid 39050

Ravinder Kaur

July 1991

A. Sloan 35108

Rosemary Bellew

July 1991

C. Cristobal 33640

Christopher Dougherty July 1991

C. Cristobal 33640

July 1991

S. King-Watson 31047 